\title{
Tyrosine Kinase Activity Is Necessary for Growth Factor-Stimulated Rabbit Type II Pneumocyte Proliferation
}

\author{
PATRICIA R. CHESS, RITA M. RYAN, AND JACOB N. FINKELSTEIN
}

Departments of Pediatrics and Environmental Health Sciences, University of Rochester, Strong Children's Research Center, Rochester, New York 14642

\section{ABSTRACT}

\begin{abstract}
Tyrosine kinases are important in the signal transduction of a number of growth factors. As shown previously, transforming growth factor (TGF)- $\alpha$ stimulated proliferation of type II cells in vitro. The mitogenic effect of TGF- $\alpha$ could be blocked by the addition of the tyrosine kinase inhibitors genistein or tyrphostin. Tyrosine phosphorylation in type II cells exposed to growth factors was examined using an antiphosphotyrosine antibody. After addition of TGF- $\alpha$, phosphorylation of a tyrosine protein with a molecular mass of $170 \mathrm{kD}$, presumed to be the epidermal growth factor receptor (EGF-R), peaked by $5 \mathrm{~min}$, returning to baseline by $30 \mathrm{~min}$. As expected, genistein or tyrphostin decreased the TGF- $\alpha$-induced phosphorylation of the EGF-R. Addition of TGF- $\beta$ resulted in no newly phos-
\end{abstract}

Growth factors are important mediators of cellular functions in many systems, including normal pulmonary development (1-3). In addition, they are thought to play a role in the lung's response to cell injury (4). Type II alveolar epithelial cells are also important in lung injury, because they proliferate and differentiate into pulmonary type I cells during the process of epithelial regeneration $(5,6)$. The mechanism of this transformation is not well understood, but it is most likely regulated by growth factors.

Growth factors that are involved in pulmonary type II epithelial cell proliferation and differentiation include EGF, TGF- $\alpha$, and TGF- $\beta$. EGF has been shown to accelerate fetal lung maturation in vivo (7-9). EGF and TGF- $\alpha$ have $40 \%$ homology and have similar biologic effects $(10,11)$. Both EGF and TGF- $\alpha$ exert their effects by binding to the EGF-R, a $170-\mathrm{kD}$ protein. Upon EGF or TGF- $\alpha$ binding to the membrane-bound EGF-R, the receptor dimerizes and a tyrosine kinase is activated, leading to autophosphorylation of the receptor (12-16). This

Received February 4, 1994; accepted May 18, 1994.

Correspondence: Patricia R. Chess, M.D., Strong Children's Research Center, Box 651, 601 Elmwood Ave., University of Rochester, Rochester, NY 14642.

Supported in part by Specialized Center of Research Grant HL36543. P.R.C. is the recipient of NIH Pulmonary Fellowship Training Grant 5T32HL07216-17. phorylated tyrosine proteins. TGF- $\beta$ decreased the TGF$\alpha$-induced phosphorylation of the EGF-R. Previous work has shown that TGF- $\beta$ blocks the TGF- $\alpha$ stimulation of type II cell proliferation. It appears that TGF- $\beta$ interferes with TGF- $\alpha$-induced phosphorylation of the EGF-R. (Pediatr Res 36: 481-486, 1994)

$\quad$ Abbreviations
TGF, transforming growth factor
EGF, epidermal growth factor
EGF-R, epidermal growth factor-receptor
TBS, Tris-buffered saline
${ }^{3}$ H-TdR, tritiated thymidine
PDGF, platelet-derived growth factor

is the first step initiating a complex cytosolic signal transduction cascade that ultimately results in gene transcription in the nucleus (17-19).

TGF- $\beta$ inhibits basal proliferation of type II pneumocytes, as well as the enhanced proliferation of type II pneumocytes, in response to EGF or TGF- $\alpha$ (20). TGF- $\beta$ signal transduction is not well understood, although its type II receptor is believed to be a serine/threonine kinase (21). The specific mechanism involved in TGF- $\beta$ antagonism of the proliferative effect of EGF and TGF- $\alpha$ is also unknown, although activation of a serine/ threonine phosphatase in a step beyond activation of the TGF- $\beta$ receptor has been implicated in other systems $(22$, 23). The present work examines the signal transduction events that occur in type II cells after addition of TGF- $\alpha$, TGF- $\beta$, and tyrosine kinase inhibitors. Cell proliferation was examined using ${ }^{3} \mathrm{H}-\mathrm{TdR}$ incorporation with cell counting to corroborate results. The tyrosine kinase inhibitors used were genistein and tyrphostin. Genistein preferentially inhibits ATP binding to a tyrosine kinase rather than serine or threonine kinases, especially at lower concentrations (24). Tyrphostin is a more specific competitive inhibitor of a growth factor substrate binding to a tyrosine kinase $(25,26)$. 


\section{METHODS}

Adult male New Zealand White rabbits were euthanized with approximately $70 \mathrm{mg} / \mathrm{kg}$ pentobarbital. Newborn rabbits were used for inhibitor concentration curve studies, with results confirmed in adults. Animals were approved for use and handled as instructed by the University Committee on Animal Resources. The lungs were removed, and type II cells were isolated and cultured on collagen-coated 12 -well plates at $2 \times 10^{6}$ cells per well using the technique previously described by Finkelstein and Shapiro (27). Using tannic acid staining (28), it has been routine in our laboratory to obtain $92 \%$ cell purity of type II cells in culture $22 \mathrm{~h}$ after plating (20).

Thymidine incorporation studies. Preliminary studies were performed in A549 cells (a human adenocarcinoma cell line) to estimate the range of concentrations of tyrosine kinase inhibitors needed for type II cell concentration curves. After $22 \mathrm{~h}$ in culture in DME/F12 (Sigma Chemical Co., St. Louis, MO) with $10 \%$ FCS, incubating at standard conditions of $37^{\circ} \mathrm{C}$ and $5 \% \mathrm{CO}_{2}$, type II cells were exposed to serum-free DME/F12 and incubated for $2 \mathrm{~h}$. Cells were then pretreated with the tyrosine kinase inhibitors genistein at $0.1-20 \mu \mathrm{M}$ or tyrphostin at $7.5-30$ $\mu \mathrm{M}$, (GIBCO BRL, Grand Island, NY) in serum-free $\mathrm{DME} / \mathrm{F} 12$ with $5 \mu \mathrm{Ci} / \mathrm{mL}^{3} \mathrm{H}$-TdR (Amersham, Arlington Heights, IL) for $24 \mathrm{~h}$. Assays for lactate dehydrogenase (Sigma Chemical Co.) were performed in triplicate on cells exposed to $10 \mu \mathrm{M}$ genistein or $30 \mu \mathrm{M}$ tyrphostin, the concentrations used for later experiments, to confirm cell viability. Cells were rinsed with PBS four times, 5\% trichloroacetic acid two times, and PBS two times. Cells were collected with three $500-\mu \mathrm{L}$ aliquots of $0.1 \mathrm{M} \mathrm{NaOH}$ and added to $10 \mathrm{~mL}$ of scintillation fluid (National Diagnostic, Manville, NJ), and $100 \mu \mathrm{L}$ of $10 \%$ acetic acid were added to neutralize the samples. Samples were allowed to equilibrate overnight before counting with a Beckman LS 7500 scintillation counter. After incubating for $22 \mathrm{~h}$ in DME/F12 with $10 \% \mathrm{FCS}$, cells were incubated in serum-free DME/F12 for $2 \mathrm{~h}$. Cells were then pretreated with genistein $(10 \mu \mathrm{M})$ or tyrphostin $(30 \mu \mathrm{M})$ in serum-free DME/F12 for $2 \mathrm{~h}$. Medium was then changed to include inhibitors with or without TGF- $\alpha(10 \mathrm{ng} / \mathrm{mL})$ or TGF- $\beta$ (10 ng/mL) (Collaborative, Bedford, MA) in DME/F12 with $5 \mu \mathrm{Ci} / \mathrm{mL}^{3} \mathrm{H}$-TdR and incubated for $24 \mathrm{~h}$. Samples were collected and counted as previously described. Cell counting was performed in triplicate for several experiments. Cells were counted while plated using a gridded eyepiece (29).

Western blot analysis. Type II cells were isolated and cultured as previously described. Twenty-two hours after plating, cells were placed in serum-free DME/F12 and incubated for $2 \mathrm{~h}$. Cells were pretreated with genistein (10 $\mu \mathrm{M})$ or tyrphostin $(30 \mu \mathrm{M})$ for $30 \mathrm{~min}$ to $2 \mathrm{~h}$, then exposed to TGF- $\alpha(10 \mathrm{ng} / \mathrm{mL})$, TGF- $\beta(10 \mathrm{ng} / \mathrm{mL})$, or both for 30 $s$ to $30 \mathrm{~min}$. Samples were collected in $200-\mu \mathrm{L}$ Laemmli sample buffer plus $100 \mu \mathrm{M}$ Na vanadate (Fisher Scientific Co., Fair Lawn, NJ) and $30 \mathrm{mM} \mathrm{Na}$ pyrophosphate
(Sigma Chemical Co.) to inhibit dephosphorylation (30), and samples were boiled for $5 \mathrm{~min}$. Protein quantification was performed using bicinchoninic acid analysis (Pierce Chemical Co., Rockford, IL). Approximately $200 \mu \mathrm{g}$ of protein were loaded per well on an SDS (ICN, Cleveland, $\mathrm{OH})$ polyacrylamide (National Diagnostics, Manville, NJ) gel. The positive control used was phosphorylated EGF-R from A431 cells (UBI, Lake Placid, NY). The molecular weight markers were Rainbow (Amersham, Arlington Heights, IL). Electrophoresis was performed over 3 to $4 \mathrm{~h}$ at $35 \mathrm{~mA}$ per gel using a Hoefer apparatus (Hoefer, San Francisco, CA). Proteins were transferred to nitrocellulose (Schleicher and Schuell, Keene, NH) at $2.5 \mathrm{~mA} / \mathrm{cm}^{2}$ for $40 \mathrm{~min}$ using an ISS Multiblotter (Enprotech, Natick, MA) dry blotter. Protein transfer was verified using $0.2 \%$ Ponceau S (Sigma Chemical Co.) staining, which was removed using $0.1 \mathrm{M} \mathrm{NaOH}$. Nonspecific binding sites were blocked using a blocking solution composed of $5 \%$ casein in TBS with $1 \mathrm{~mL}$ of Tween 20 and $10 \mu \mathrm{L}$ of Antifoam A (Sigma Chemical Co.) per liter for $1 / 2 \mathrm{~h}$ at room temperature. The blots were then incubated overnight at $4^{\circ} \mathrm{C}$ in $10 \mathrm{~mL}$ of $1 \mu \mathrm{g} / \mathrm{mL}$ monoclonal mouse antiphosphotyrosine antibody (UBI) (31). Blots were washed with blocking solution for $2 \times 5 \mathrm{~min}$, then $1 \times 15 \mathrm{~min}$, and then incubated for $1 \mathrm{~h}$ at room temperature in $10 \mathrm{~mL}$ of $1 \mu \mathrm{g} / \mathrm{mL}$ biotinylated goat antimouse IgG (Cappel, Durham, NC). The blots were washed in blocking solution as before, then washed in TBS $2 \times 5 \mathrm{~min}$. The blots were then incubated at room temperature for $40 \mathrm{~min}$ with Vectastain horseradish peroxidase (Vector, Burlingame, CA) in TBS, then washed with blocking solution and TBS as before. The blots were incubated in enhanced chemiluminescence (Amersham) for $1 \mathrm{~min}$ and then exposed to $\mathrm{x}$-ray film (Kodak x-omatar, Rochester, NY) for 3-45 min. A Western blot was performed similarly on $200 \mu \mathrm{g}$ of rabbit type II cell protein as previously described using $10 \mathrm{~mL}$ of $1 \mu \mathrm{g} / \mathrm{mL}$ sheep anti-human EGF-R (UBI) as the primary antibody and $10 \mathrm{~mL}$ of $1 \mu \mathrm{g} / \mathrm{mL}$ biotinylated rabbit anti-sheep IgG (Chemicon, Temecula, CA) as the secondary antibody. A Western blot without the primary antibody was performed to identify nonspecific binding.

Data analysis. Analysis of variance with NewmanKeul's post-hoc test was used to compare ${ }^{3} \mathrm{H}-\mathrm{TdR}$ incorporation of control samples with that of growth factorand tyrosine kinase inhibitor-treated samples. A $p$ value of $<0.05$ was considered statistically significant.

\section{RESULTS}

Treatment of type II cells with genistein at a range of $0.1-20 \mu \mathrm{M}$ established that incubation with $<1 \mu \mathrm{M}$ genistein resulted in no inhibition of ${ }^{3} \mathrm{H}-\mathrm{TdR}$ incorporation. Maximal effect was achieved at $10 \mu \mathrm{M}$, with approximately $60 \%$ inhibition of ${ }^{3} \mathrm{H}-\mathrm{TdR}$ incorporation compared with control (Fig. 1A). Treatment with tyrphostin at a range of 3-30 $\mu \mathrm{M}$ established that treatment with $<10 \mu \mathrm{M}$ tyrphostin resulted in no inhibition of 
${ }^{3} \mathrm{H}$-TdR incorporation, and treatment with $30 \mu \mathrm{M}$ resulted in optimal inhibition, approximately $60 \%$ inhibition compared with control (Fig. 1B). Assays for lactate dehydrogenase confirmed no change in cell viability at 10 $\mu \mathrm{M}$ genistein and $30 \mu \mathrm{M}$ tyrphostin (data not shown).

Exposure of type II cells to genistein $(10 \mu \mathrm{M})$ or tyrphostin $(30 \mu \mathrm{M})$ resulted in significant inhibition of basal ${ }^{3} \mathrm{H}$-TdR incorporation $(p<0.05)$ (Fig. 2$)$, as well as blocking of the increased ${ }^{3} \mathrm{H}$-TdR incorporation seen in response to TGF- $\alpha(p<0.05)$ (Fig. 3). Cell counting confirmed ${ }^{3} \mathrm{H}$-TdR incorporation results, with $60-70 \%$ inhibition of both ${ }^{3} \mathrm{H}$-TdR incorporation and cell number (insets, Figs. 2 and 3).
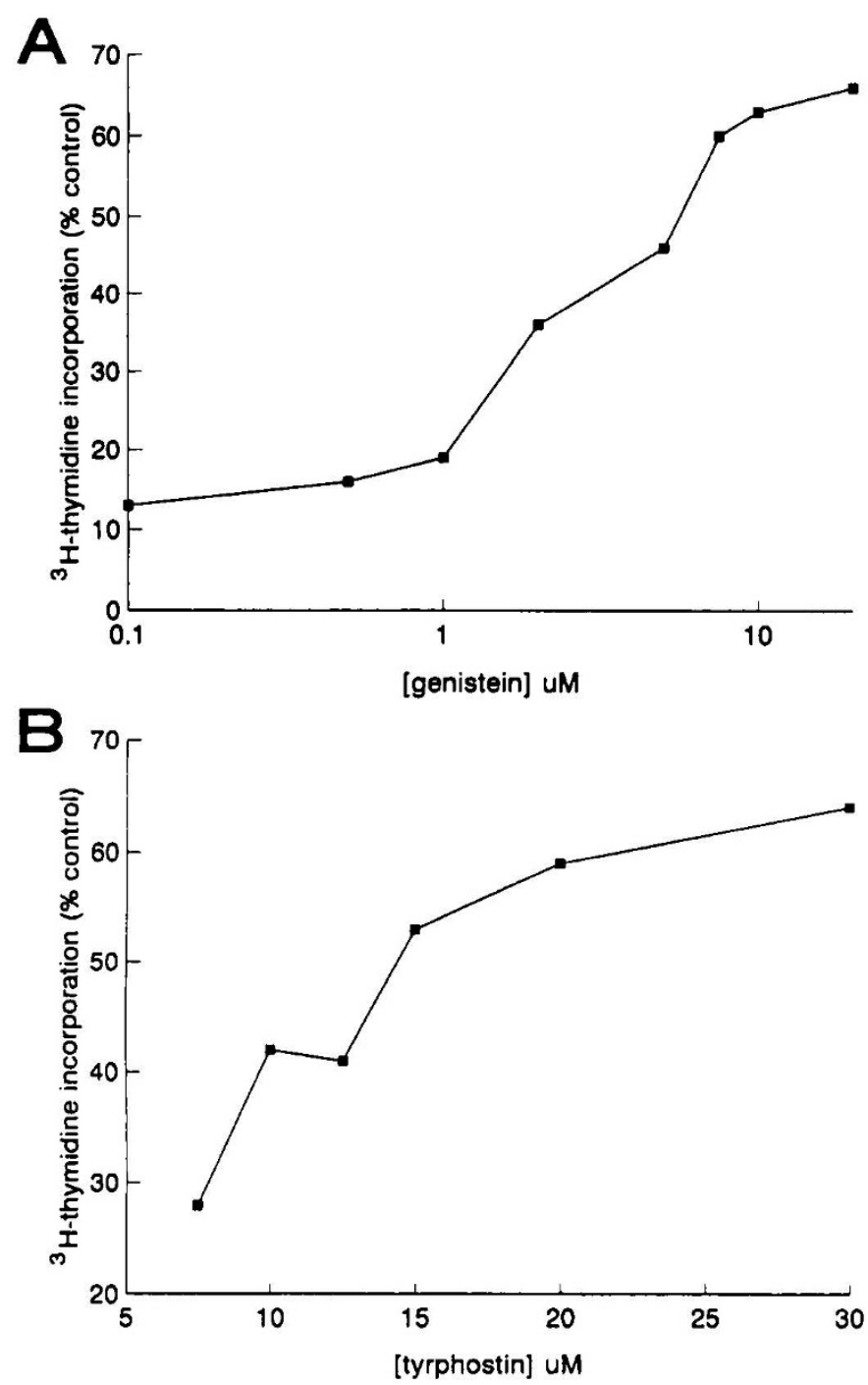

Figure 1. $A$, Effects of genistein concentration on ${ }^{3} \mathrm{H}-\mathrm{TdR}$ incorporation in isolated rabbit type II cells. Type II cells were isolated and plated for $22 \mathrm{~h}$. They were then pretreated for $2 \mathrm{~h}$ with $0.1-20 \mu \mathrm{M}$ genistein and incubated for $24 \mathrm{~h}$. Values are expressed as a percentage of control. Experiments were performed in triplicate; $n=2$. $B$, Effect of tyrphostin concentration on ${ }^{3} \mathrm{H}-\mathrm{TdR}$ incorporation in isolated rabbit type II cells. Type II cells were isolated and plated for $22 \mathrm{~h}$. They were then pretreated for $2 \mathrm{~h}$ with 7.5-30 $\mu \mathrm{M}$ tyrphostin and incubated for 24 h. Values are expressed as a percentage of control. Experiments were performed in triplicate; $n=1$.

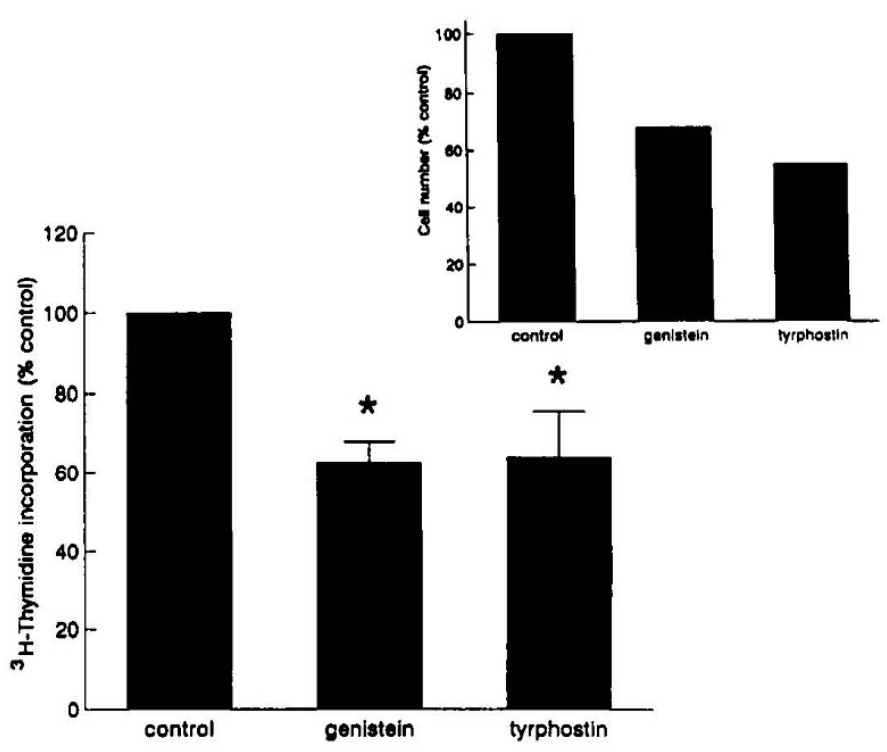

Figure 2. Tyrosine kinase inhibitors decrease basal ${ }^{3} \mathrm{H}-\mathrm{TdR}$ incorporation and cell proliferation in isolated rabbit type II cells. Type II cells were isolated and plated for $22 \mathrm{~h}$. They were then pretreated for $2 \mathrm{~h}$ with $10 \mu \mathrm{M}$ genistein or $30 \mu \mathrm{M}$ tyrphostin and incubated for $24 \mathrm{~h}$. All values are expressed as a percentage of control (mean \pm SEM). Experiments were performed in triplicate with $n=4$. Basal ${ }^{3} \mathrm{H}$-TdR incorporation inhibition was statistically significant $\left({ }^{*}, p<0.05\right.$ by analysis of variance). Inset shows cell number as a percentage of control, performed in triplicate; $n=1-2$.

To examine further the effects of TGF- $\alpha$ on type II cell proliferation, tyrosine phosphorylation was studied. An antiphosphotyrosine antibody was used to examine the response of type II cells to growth factors. As expected, addition of TGF- $\alpha$ resulted in phosphorylation of a

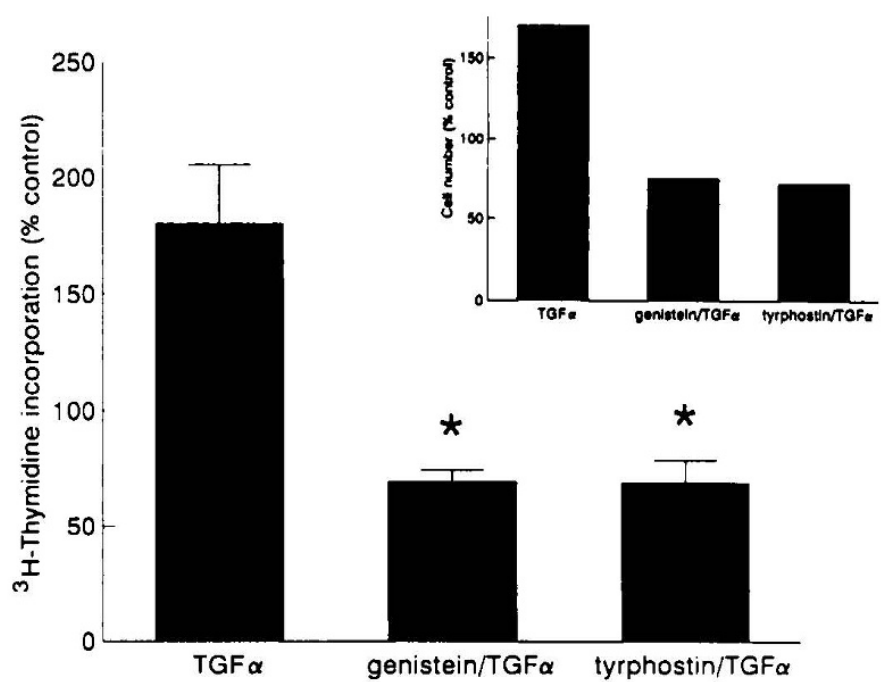

Figure 3. Tyrosine kinase inhibitors decreased ${ }^{3} \mathrm{H}-\mathrm{TdR}$ incorporation and cell number in isolated rabbit type II cells in response to TGF- $\alpha$. Type II cells were isolated and plated for $22 \mathrm{~h}$. They were then pretreated for $2 \mathrm{~h}$ with $10 \mu \mathrm{M}$ genistein or $30 \mu \mathrm{M}$ tyrphostin followed by $10 \mathrm{ng} / \mathrm{mL}$ TGF- $\alpha$ and incubated for $24 \mathrm{~h}$. Experiments were performed in triplicate with $n=4$. All values are expressed as a percentage of control (mean $\pm S E M)$. Inhibition of TGF- $\alpha$-induced ${ }^{3} \mathrm{H}-\mathrm{TdR}$ incorporation was statistically significant $\left({ }^{*}, p<0.05\right.$ by analysis of variance). Inset shows cell number as a percentage of control, performed in triplicate; $n=1-2$. 
$170-\mathrm{kD}$ protein corresponding to the known size of the EGF-R by $30 \mathrm{~s}$, peaking by $5 \mathrm{~min}$, and returning nearly to baseline by $30 \mathrm{~min}$ (Fig. 4). Also as expected, the tyrosine kinase inhibitors genistein or tyrphostin inhibited phosphorylation of the presumed EGF-R previously seen in response to TGF- $\alpha$ (Fig. 5). The inhibition by genistein did not appear to be altered by timing of treatment. The inhibition by tyrphostin was more pronounced when cells were pretreated with tyrphostin for $30 \mathrm{~min}$ before addition TGF- $\alpha$ compared with addition of tyrphostin and TGF- $\alpha$ simultaneously. An anti EGF-R antibody confirmed the presence of the EGF-R at $170 \mathrm{kD}$ (Fig. 6).

Exposure of type II cells to TGF- $\beta$ resulted in no newly tyrosine-phosphorylated proteins within $\mathbf{3 0}$ min (Fig. 7). Pretreatment with TGF- $\beta$ for $30 \mathrm{~min}$ resulted in decreased phosphorylation of the presumed EGF-R previously seen in response to TGF- $\alpha$ (Fig. 8).

\section{DISCUSSION}

Previous work has established the importance of protein kinases in regulating cellular functions in type II cells. Protein kinase $\mathrm{C}$ and cAMP-dependent protein kinase are important in the regulation of surfactant secretion (32-34). cAMP-dependent protein kinase activity has been found to be altered at various states of development in the rat lung, possibly to mediate developmental changes in pulmonary response to hormonal stimuli (35). Actin, a cytoskeletal protein involved in regulating type II cell shape and mobility, is phosphorylated via a cAMPdependent protein kinase (36). Tyrosine kinase activity in type II cells in response to TGF- $\alpha$ and TGF- $\beta$ has not yet been studied.

The results of the current work suggest that tyrosine kinases are important in basal type II cell proliferation in vitro as measured by ${ }^{3} \mathrm{H}$-TdR incorporation and cell counting, inasmuch as known tyrosine kinase inhibitors were capable of reducing basal proliferation. In the rat type II cell in vitro, TdR incorporation has not always been associated with a concomitant increase in cell number (37). However, in rabbit type II cell proliferation studies, cell number correlated with ${ }^{3} \mathrm{H}$-TdR incorporation (20). In addition to species differences, other factors such as cell density and matrix components may also

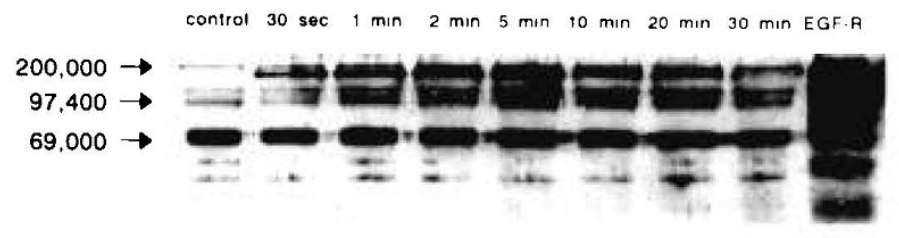

Figure 4. TGF- $\alpha$ resulted in rapid phosphorylation of a $170-\mathrm{kD}$ tyrosine protein presumed to be the EGF-R. Rabbit type II cells were isolated and plated for $24 \mathrm{~h}$, then treated with $10 \mathrm{ng} / \mathrm{mL}$ TGF- $\alpha$ for $30 \mathrm{~s}$ to $30 \mathrm{~min}$. Cells were collected in Laemmli sample buffer and subjected to SDS-PAGE using a $12 \%$ gel followed by Western blot analysis with an antiphosphotyrosine antibody. Molecular masses are indicated on the left in daltons.
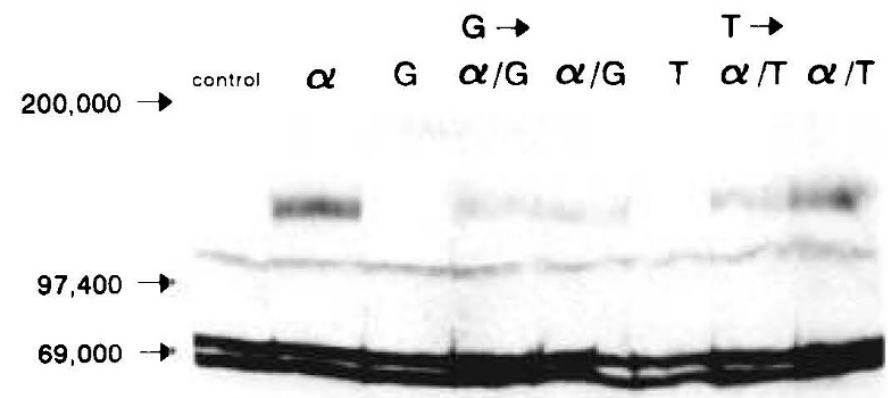

Figure 5. Tyrosine kinase inhibitors blocked TGF- $\alpha$-induced phosphorylation of the presumed EGF-R. Rabbit type II cells were isolated and plated for $24 \mathrm{~h}$ (control), pretreated for $30 \mathrm{~s}$ with $10 \mathrm{ng} / \mathrm{mL}$ TGF- $\alpha$ (lane $\alpha$ ), pretreated for $30 \mathrm{~min}$ with $10 \mu \mathrm{M}$ genistein or $30 \mu \mathrm{M}$ tyrphostin (lanes $G$ and $T$ ), pretreated for $30 \mathrm{~min}$ with $10 \mu \mathrm{M}$ genistein or $30 \mu \mathrm{M}$ tyrphostin, then treated with $10 \mathrm{ng} / \mathrm{mL}$ TGF- $\alpha$ for $30 \mathrm{~s}$ (lanes $G \rightarrow \alpha / G$ and $T \rightarrow \alpha / T)$, or treated with inhibitor plus TGF- $\alpha$ simultaneously for $30 \mathrm{~s}$ (lanes $\alpha / G$ and $\alpha / T$ ). Cells were collected in Laemmli sample buffer and subjected to SDS-PAGE using a 3-17\% gradient gel followed by Western blot analysis with an antiphosphotyrosine antibody. Molecular masses are indicated on the left in daltons.

play a role in the relationship between ${ }^{3} \mathrm{H}-\mathrm{TdR}$ incorporation and cell number.

One factor to consider in analyzing and interpreting the data using tyrosine kinase inhibitors is that tyrosine kinases are ubiquitous within living cells. By using tyrosine kinase inhibitors, we may be affecting other vital cellular functions (38). These effects may be somewhat mitigated by using tyrphostin, a more specific antagonist of the

\section{0,000 EGF-R

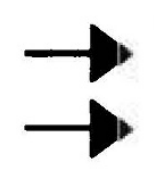

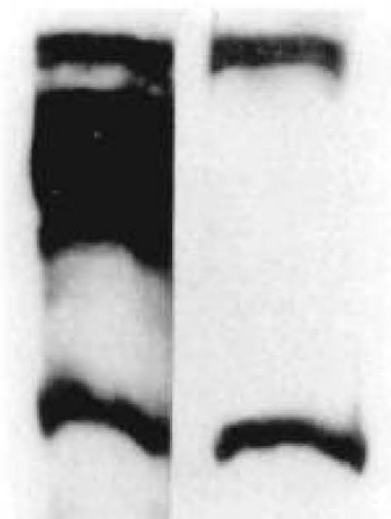

\section{$97,400 \rightarrow$}
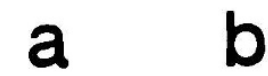

Figure 6. The EGF-R was identified in isolated rabbit type II cells at $170 \mathrm{kD}$. Type II cells were isolated and plated for $24 \mathrm{~h}$. Cells were collected in Laemmli sample buffer and subjected to SDS-PAGE using an $8 \%$ gel followed by Western blot analysis with (lane $a$ ) or without (lane $b$ ) an anti-EGF-R antibody. Molecular masses are indicated on the left in daltons. 


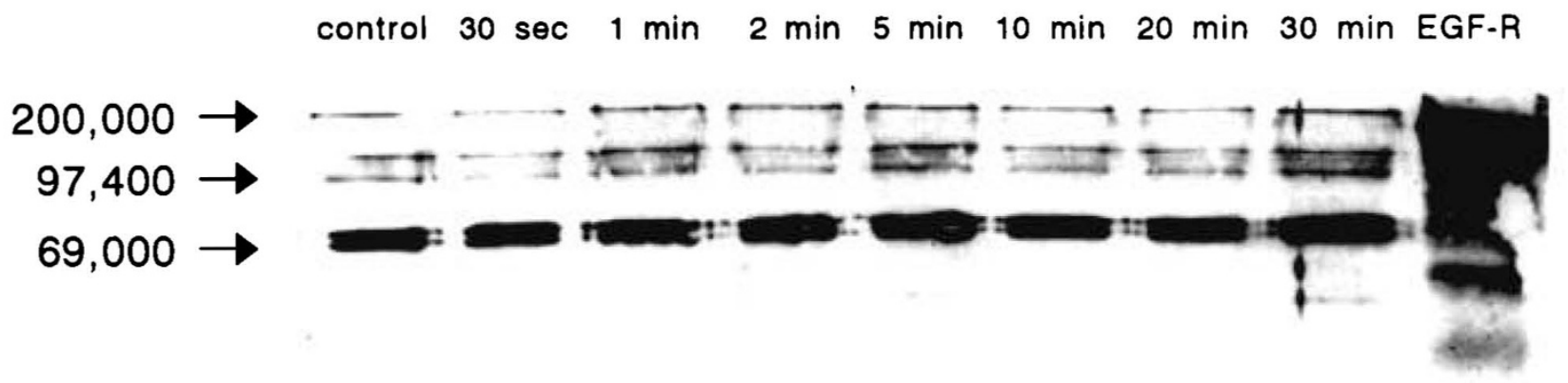

Figure 7. Treatment of isolated rabbit type II cells with TGF- $\beta$ resulted in no newly phosphorylated tyrosine proteins. Type II cells were isolated and plated for $22 \mathrm{~h}$, then treated with $10 \mathrm{ng} / \mathrm{mL}$ TGF- $\beta$ for $30 \mathrm{~s}$ to $30 \mathrm{~min}$. Cells were collected in Laemmli sample buffer and subjected to SDS-PAGE using a $12 \%$ gel followed by Western blot analysis with an antiphosphotyrosine antibody. Molecular masses are indicated on the left in daltons.

EGF-R tyrosine kinase, and by minimizing exposure times $(25,26)$. It appears that in our system the cellular function affected is specific, inasmuch as tyrphostin and genistein, with different mechanisms of action, achieve similar effects.

Phosphorylation of the EGF-R is a crucial step in the signal transduction pathway initiated by TGF- $\alpha$ in type II cells. This event peaks by $30 \mathrm{~s}$ to $5 \mathrm{~min}$, a time course comparable to EGF studies in other cell systems $(17,18)$. Pretreatment with tyrphostin resulted in more inhibition of EGF-R phosphorylation than simultaneous addition with TGF- $\alpha$, whereas timing of genistein had little effect. This may be due to tyrphostin being a more specific tyrosine kinase inhibitor or to the cells not being synchronous in their cell cycles.

We have demonstrated that TGF- $\beta$ decreases the level of phosphorylation of the EGF-R in response to TGF- $\alpha$. One possible explanation is that TGF- $\beta$ affects TGF- $\alpha$ binding to its receptor. In previous studies in our laboratory, TGF- $\beta$ had no effect on EGF binding to the EGF-R for up to $20 \mathrm{~min}$ (39). This is similar to the time course of the EGF-R phosphorylation we studied. Alternatively, TGF- $\beta$ may enhance dephosphorylation of the EGF-R in response to TGF- $\alpha$. Fontenay et al. (22) have demonstrated a similar effect of TGF- $\beta$ decreasing the PDGFinduced phosphorylation of the PDGF receptor, another

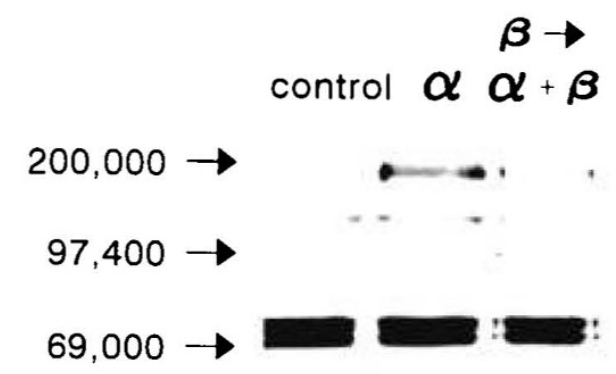

Figure 8. TGF- $\beta$ decreased the phosphorylation of the $170-\mathrm{kD}$ tyrosine protein previously phosphorylated after treatment with TGF- $\alpha$. Type II cells were plated for $22 \mathrm{~h}$, then pretreated for $30 \mathrm{~s}$ with $10 \mathrm{ng} / \mathrm{mL}$ TGF- $\alpha$ (lane $\alpha$ ), or pretreated for $30 \mathrm{~min}$ with $10 \mathrm{ng} / \mathrm{mL} \mathrm{TGF}-\beta$, then treated with $10 \mathrm{ng} / \mathrm{mL}$ TGF- $\alpha$ for $30 \mathrm{~s}$ (lane $\beta \rightarrow \alpha+\beta$ ). Samples were collected with Laemmli sample buffer and subjected to SDS-PAGE using a $10 \%$ gel followed by Western blot analysis with an antiphosphotyrosine antibody. Molecular masses are indicated on the left in daltons. tyrosine kinase receptor. In their work using human passaged fibroblasts, it appears that TGF- $\beta$ exerts its inhibitory effects on PDGF via serine/threonine phosphatase activity, resulting in accelerated dephosphorylation of the PDGF receptor. Kim et al. (23) have demonstrated that okadaic acid, a protein phosphatase inhibitor, blocks the proliferative effect of TGF- $\beta$ on mouse fibroblasts, even when added $10 \mathrm{~h}$ after TGF- $\beta$ treatment. This again supports the involvement of a protein phosphatase beyond the initial activation of the TGF- $\beta$-receptor complex in the TGF- $\beta$ signal cascade.

In conclusion, we have demonstrated that tyrosine kinase activity is important in type II pneumocyte proliferation in vitro. TGF- $\alpha$, known to stimulate type II cell proliferation, exerts its effects via phosphorylation of a $170-\mathrm{kD}$ protein, presumed to be the EGF-R. In examining the mechanism by which TGF- $\beta$ blocks the TGF- $\alpha$ mitogenic effect on type II cells, we have demonstrated that TGF- $\beta$ decreases the normal TGF- $\alpha$-induced phosphorylation of the EGF-R. Additional studies are needed to determine the specific mechanism by which TGF- $\beta$ affects EGF-R phosphorylation.

Acknowledgments. The authors thank Dr. Robert Swantz for critical review of this manuscript and Christina Reed and Anna Paxhia for their technical assistance.

\section{REFERENCES}

1. Pouyssegur J, Seuwen K 1992 Transmembrane receptors and intracellular pathways that control cell proliferation. Annu Rev Physiol 54:195-210

2. Olashaw NE, Olson JE, Drozdoff V, Pledger WJ 1992 Growth factors: their role in the control of cell proliferation. In: Stein GS, Lian JB (eds) Molecular and Cellular Approaches to the Control of Proliferation and Differentiation. Academic Press, San Diego, pp 3-26

3. Soprano KJ, Cosenza SC 1992 Cell cycle and cell growth control. In: Stein GS, Lian JB (eds) Molecular and Cellular Approaches to the Control of Proliferation and Differentiation. Academic Press, San Diego, pp 73-114

4. Stahlman MT, Orth DN, Gray ME 1989 Immunocytochemical localization of epidermal growth factor in the developing human respiratory system and in acute and chronic lung disease in the neonate. Lab Invest 60:539-547

5. Mason RJ, Williams MC 1991 The Lung. Raven Press, New York, pp 235-246

6. Evans MJ, Cabral LJ, Stephens RJ, Freeman G 1975 Transformation of alveolar type II cells following exposure to $\mathrm{NO}_{2}$. Exp Mol Pathol 22:142-150

7. Sundell HW, Gray ME, Serenius FS, Escobedo MB, Stahlman MT 1980 Effects of epidermal growth factor on lung maturation in fetal lambs. Am J Pathol 100:707-719

8. Catterton WZ, Escobedo MB, Sexton WR, Gray ME, Sundell HW, Stahlman MT 1979 Effect of epidermal growth factor on lung maturation in fetal rabbits. Pediatr Res 13:104-108 
9. Plopper CG, St. George JA, Reed LC, Nishio SJ, Weir AJ, Edwards L, Tarantal AF, Pinkerton KE, Merritt TA, Whitsett JA, George-Nascimento C, Styne D 1992 Acceleration of alveolar type II cell differentiation in fetal rhesus monkey lung administration of EGF. Am J Physiol 262:L313-L321

10. King RJ, Jones MB, Minoo P 1989 Regulation of lung cell proliferation by polypeptide growth factors. Am J Physiol 257:L23-L38

11. Lyons RM, Moses HL 1990 Transforming growth factors and the regulation of cell proliferation. Eur J Biochem 187:467-473

12. Stoscheck CM, King Jr LE 1986 Functional and structural characteristics of EGF and its receptor and their relationship to transforming proteins. J Cell Biochem 31:135-152

13. Comoglio PM, DiRenzo MF, Gaudino G, Ponzetto C, Prat M 1990 Tyrosine kinase and control of cell proliferation. Am Rev Respir Dis 142:S16-S19

14. Hunter T 1991 Protein kinase classification. Methods Enzymol 200:3-36

15. Yarden Y, Ullrich A 1988 Growth factor receptor tyrosine kinases. Ann Rev Biochem 57:443-478

16. Reynolds FH, Todaro GJ, Fryling C, Stevenson JR 1981 Human transforming growth factors (TGFs) induce tyrosine phosphorylation of EGF receptors. Nature 292:259-262

17. Liang M, Garrison J 1991 The epidermal growth factor receptor is coupled to a pertussis toxin sensitive guanine nucleotide regulatory protein in rat hepatocytes. J Biol Chem 266:13342-13349

18. Fazioli F, Bottaro DP, Minichiello L, Auricchio A, Wong W, Segatto O, DiFiore PP 1992 Identification and biochemical characterization of novel putative substrates for the epidermal growth factor receptor kinase. J Biol Chem 267:5155-5161

19. Fox CF, Das M 1979 Internalization and processing of the EGF receptor in the induction of DNA synthesis in cultured fibroblasts: the endocytic activation hypothesis. J Supramol Struct 10:199-214

20. Ryan RM, Mineo-Kuhn MM, Kramer CM, Finkelstein JN 1994 Growth factors alter neonatal type II alveolar epithelial cell proliferation. Am J Physiol 266:L17-L22

21. Ebner R, Chen R, Shum L, Lawler S, Zioncheck TF, Lee A, Lopez AR, Derynck R 1993 Cloning of a type I TGF- $\beta$ receptor and its effect on TGF- $\beta$ binding to the type II receptor. Science 260:1344-1348

22. Fontenay M, Bryckaert M, Tobelem G 1992 Transforming growth factor $\beta 1$ inhibitory effect of platelet-derived growth factor-induced signal transduction on human bone marrow fibroblasts: possible involvement of protein phosphatases. J Cell Physiol 152:507-519

23. Kim T, Velasquez BR, Wenner CE 1993 Okadaic acid regulation of the retinoblastoma gene product is correlated with the inhibition of growth factor-induced cell proliferation in mouse fibroblasts. Proc Natl Acad Sci USA $90: 5460-5463$
24. Akiyama T, Ogawara H 1991 Use and specificity of genistein as inhibitor of protein-tyrosine kinases. Methods Enzymol 201:362-370

25. Workman P, Brunton VG, Robins DJ 1992 Tyrosine kinase inhibitors. Semin Cancer Biol 3:369-381

26. Gazit A, Yaish P, Gilon C, Levitzki A 1989 Tyrphostins I: synthesis and biological activity of protein tyrosine kinase inhibitors. J Med Chem 32:2344 2352

27. Finkelstein JN, Shapiro DL 1982 Isolation of type II alveolar epithelial cells using low protease concentrations. Lung 160:85-92

28. Mason RJ, Walker SR, Shields BA, Henson JE, Williams MC 1985 Identification of rat alveolar type II cells with a tannic acid and polychrome stain. Am Rev Respir Dis 131:786-788

29. Everett MM, Miller WA 1980 Normal statistics applied to non-distructive cell counting techniques. J Tissue Cult Methods 6:29-31

30. Guy GR, Cao X, Chua SP, Tan YH 1992 Okadaic acid mimics multiple changes in early protein phosphorylation and gene expression induced by tumor necrosis factor or interleukin-1. J Biol Chem 267:1846-1852

31. Kozma LM, Rossomando AJ, Weber MJ 1991 Comparison of three methods for detecting tyrosine-phosphorylated proteins. Methods Enzymol 201: $28-43$

32. Rice WR, Hull WM, Dion CA, Hollinger BA, Whitsett JA 1985 Activation of cAMP dependent protein kinase during surfactant release from type II pneumocytes. Exp Lung Res 9:135-149

33. Warburton D, Tayag A, Buckley S, Cosico L, Seth R 1991 Protein phosphorylation and dephosphorylation in type Il pneumocytes. Am J Physiol 260:L548-L.553

34. Sano K, Voelker DR, Mason RJ 1985 Involvement of protein kinase C in pulmonary surfactant secretion from alveolar type II cells. J Biol Chem 260:12725-12729

35. Whitsett JA, Matz S, Darovec-Beckerman C 1983 cAMP-dependent protein kinase and protein phosphorylation in developing rat lung. Pediatr Res 17:959-966

36. Whitsett JA, Hull W, Dion C, Lessard J 1985 cAMP dependent actin phosphorylation in developing rat lung and type Il epithelial cells. Exp Lung Res 9:191-209

37. Clement A, Reidel N, Brody JS $1990\left[{ }^{3} \mathrm{H}\right]$ Thymidine incorporation does not correlate with growth state in cultured alveolar type II cells. Am J Respir Cell Mol Biol 3:159-164

38. Young SW, Poole RC, Hudson AT, Halestrap AP, Denton RM, Tavare JM 1993 Effects of tyrosine kinase inhibitors on protein kinase independent systems. FEBS Lett 316:278-282

39. Brandes ME 1989 Modulation of type II pneumocyte proliferation after lung injury by alveolar macrophage-derived growth factors. PhD thesis, University of Rochester, Rochester, NY 